\title{
UNUSUAL STRUCTURES IN THE PALEOZOIC INSECT ORDERS MEGASECOPTERA AND PALAEODICTYOPTERA, WITH A DESCRIPTION OF A NEW FAMILY*
}

\author{
By Jarmila Kukalová-Peck \\ Department of Geology, Carleton University, \\ Ottawa, Ontario, Canada
}

The order Megasecoptera is a representative of the haustellate paleopterous insects of the evolutionary line that lived during the Pennsylvanian and the Permian. The similarity of wings and body structures, such as mouth-parts and genitalia, indicate very close relationship with the order Palaeodictyoptera. Both groups are presumed to have emerged sometime during the Mississippian from a common ancestor. While Palaeodictyoptera are usually larger and more sturdily built, bearing broad wings with a rich venation and prothoracic lobes, Megasecoptera are slender insects with a more delicate appearance, with petiolate wings and simplified venation, with enlarged thorax lacking prothoracic lobes, and with tapering abdomen.

The present paper deals with an extraordinary morphological feature - projections of the body cuticle, which occur in most or all Megasecoptera and at least in some Palaeodictyoptera. These are conspicuous processes, which are short to very long, simple or branched, and which are distributed in regular rows on the abdomen and thorax.

A fuller understanding of the morphology of this very unusual character resulted from two years of intensive research by Dr. F. M. Carpenter and myself, based upon fossil material of Commentry (Upper Pennsylvanian, France), Mazon Creek (Middle Pennsylvanian, Illinois), Obora (Lower Permian, Czechoslovakia), Elmo (Lower Permian, Kansas), and now also Tshekarda (Lower Permian, Siberia). I am deeply indebted to Professor Carpenter, who was very helpful in the preparation of this study.

Until now, the projections have been only poorly known. They were at first mostly interpreted as tracheal gills that persisted into the

*This study has been supported in part by grant No. GB-27333 (F. M. Carpenter, Principal investigator, Harvard University) from the National Science Foundation.

Manuscript received by the editor July 15, 1972. 
adult stage, or later as short lateral spines on the abdominal segments and thorax. The following is a short account of present knowledge.

The projections on the prothorax are, in some families, long and filiform, but in other families rather short, pointed and spine-like. They were described as spines in some Megasecoptera, namely in Mischoptera, Aspidothorax, Corydaloides and Foriria by Brongniart (1885 ab, I890, 1893), Lameere (1908, 1917), Carpenter (I95 I, I968) and others. In 1968 Carpenter and Richardson mentioned stout lateral spines in the nymph of Mischoptera douglassi on the mesoand metathorax.

The abdominal projections are actually filiform, growing in fringelike rows out of the tergites. However, all previous authors observed only the basal parts of several abdominal projections situated laterally, which led to incorrect interpretations. Thus Brongniart ( 1885, p. $63 ; \mathrm{s} 885$, p. $658 ; 1890$, p. I 540 ) considered them to be branchio-tracheal appendages, which served for aquatic respiration in nymphs and which were carried over to the adults. In his general account on Carboniferous insects of Commentry, he gave a detailed figure ( 1893 , p. 305, p. 298, fig. 50) of an enlarged "lateral lamella" with branched "tracheae" in the genus Corydaloides (Mischopteridae). His point of view was followed by Brauer (1886, p. I07), who classified the projections as "persistent abdominal tracheal gills".

Handlirsch first (1906) stated that Megasecoptera possessed "dentated lamellar appendages, which were perhaps derived from tracheal gills".

The gill character of the projections was denied by Lameere ( 1908 , p. 136 ; 1917, p. 28; 1917, p. I45), who compared the "lamellae" with the lateral expansions of the Recent mayfly Oniscigaster wakefieldi (N. Zealand). He regarded the projections protruding out from "lamellae" to be backwardly directed spines.

Martynov (1938, p. 25) characterized Megasecoptera as having "lateral expansions of abdominal segments with tooth-like or spinelike outgrowths, homologous with prothoracic spines and prothoracic winglets of Palaeodictyoptera, reduced and modified". Carpenter (195I, p. 353) correctly stated that the projections were extensions of tergites, but also believed them to be short and spine-like in character (Corydaloididae, I95I, p. 35I).

A significant step in the research of the character of abdominal projections was the paper on megasecopterous nymphs published by Carpenter and Richardson (1968). In this remarkably preserved nymph, Mischoptera douglassi, the hind margins of the abdominal tergites, except the last two, bear a row of seven stout "spines". This 
fact was unusual enough to inspire the thoroughfull examination of abdominal tergites of all known Megasecoptera for this feature.

After a detailed discussion with Dr. Carpenter (during my tenure as Alexander Agassiz Lecturer in Zoology at Harvard University), I visited the Muséum d'Histoire Naturelle in Paris on my return trip to Europe. This institution's collections hold the most extensive material of Paleozoic Megasecoptera (Brongniart, I893; Carpenter, 195 I). I found that each of the sufficiently preserved megasecopteran bodies (mostly Mischopteridae) had prolonged filaments leading from the posterior margin of the abdominal tergites. The projections were visible only under glycerin, a medium which was obviously not applied to the fossils by previous students. It should be noted that in the Mischoptera douglassi nymph the bases of the projections give a perfect spine-like appearance, which now seems to be due to incomplete preservation. Recently, Carpenter and Richardson (I97I) described long filamentous projections in Eubrodia dabasinskasi (Brodiidae) extending posteriorly along the mesothorax to almost the end of the body.

The specimens of Megasecoptera and Palaeodictyoptera newly introduced in the present paper contribute significant features to the knowledge of the projections. Sylvohymen sibiricus n.sp. (Bardohymenidae), a megasecopteron from the Lower Permian of Siberia, shows the hollow, broken bases of projections located not only along the posterior margin of abdominal tergites, but also on tergal nota of the whole body (fig. I and pl. I). Monsteropterum moravicum n.sp., a palaeodictyopteron from the Lower Permian of Czechoslovakia, presents well preserved projections (fig. 6 and pl. 3), showing details of the surface and of multiple branching.

Summarizing our present knowledge, we can say that the processes or projections are hollow outgrowths of the tergites and are usually arranged into regular transverse rows, are simple or branched, and are short to very long, according to the particular families. The outgrowths are directed up and backwards from the body, so that they protrude. The ventral side of the projection-bearing bodies is not known. On the thorax, the projections may form spines, or may be filiform, identical to those on the abdomen. The abdominal projections with their superimposed series of fringes, resemble the traditional skirt of the Spanish national female costume. It is possible that all species of Megasecoptera possessed projections, more or less developed, both adults and nymphs. Projections of the same character occurred in some Palaeodictyoptera, but probably not in all families. 
It has taken almost 80 years for acquisition of the above data about these two groups of insects, though they are not rare in Paleozoic deposits. This slow process becomes more understandable after considering the character and nature of preservation of the projections. Protruding above the body in life, they tended to become hidden by the superimposed sediment rather than become compressed at the same level as the body itself during fossilization. The broken and usually more sclerotized bases of the projections are not distinguishable from spines or tubercles and are mostly inconspicuous. Finally, in a matrix which does not preserve chitin, the imprints of the projections are vague.

During my study, the projections were thoroughly examined for connections with the insect's body. In the matrix capable of preserving chitin (e.g. Commentry shale), the projections have the same brown color as the terga. Their surface is covered with a rugosity similar to that on the body (Mazon Creek, Illinois) or with a minor rugosity and scattered sockets of setae (Obora, Moravia). In Monsteropterum moravicum, the surface of the projections is identical to that of the legs. The arrangement of the projections is regular and probably characteristic for all genera within a family (I have found this to be true so far for Bardohymenidae, Protohymenidae and Mischopteridae). The width of the projections varies with the size of specimens; their arrangement is bilaterally symmetrical. The above mentioned features exclude the possibility that the outgrowths are parasitic organisms or fungi.

These projections in the Megasecoptera and Palaeodictyoptera appear unique among insect orders, and their function remains obscure. However, several features suggest that they might be homologous to certain tergal structures of Odonata. In all Recent Odonata, there is a transverse ridge at each end of the tergum, the anterior and posterior transverse carinae (Walker I953, p. I 8 ). The former is inconspicuous, but the posterior carina is a distinct ridge bearing a row of small tubercles or denticles. By the position and arrangement in rows, the projections in Megasecoptera and Palaeodictyoptera are very suggestive of the prolonged and enlarged carinal denticles of Odonata. Their function, of course, presents a complicated problem, which can hardly be solved with fossil material.

Order Megasecoptera

Family Bardohymenidae Zalessky

Type Genus: Bardohymen Zalessky, 1937.

This family was erected by G. Zalessky (1937) and redefined by 


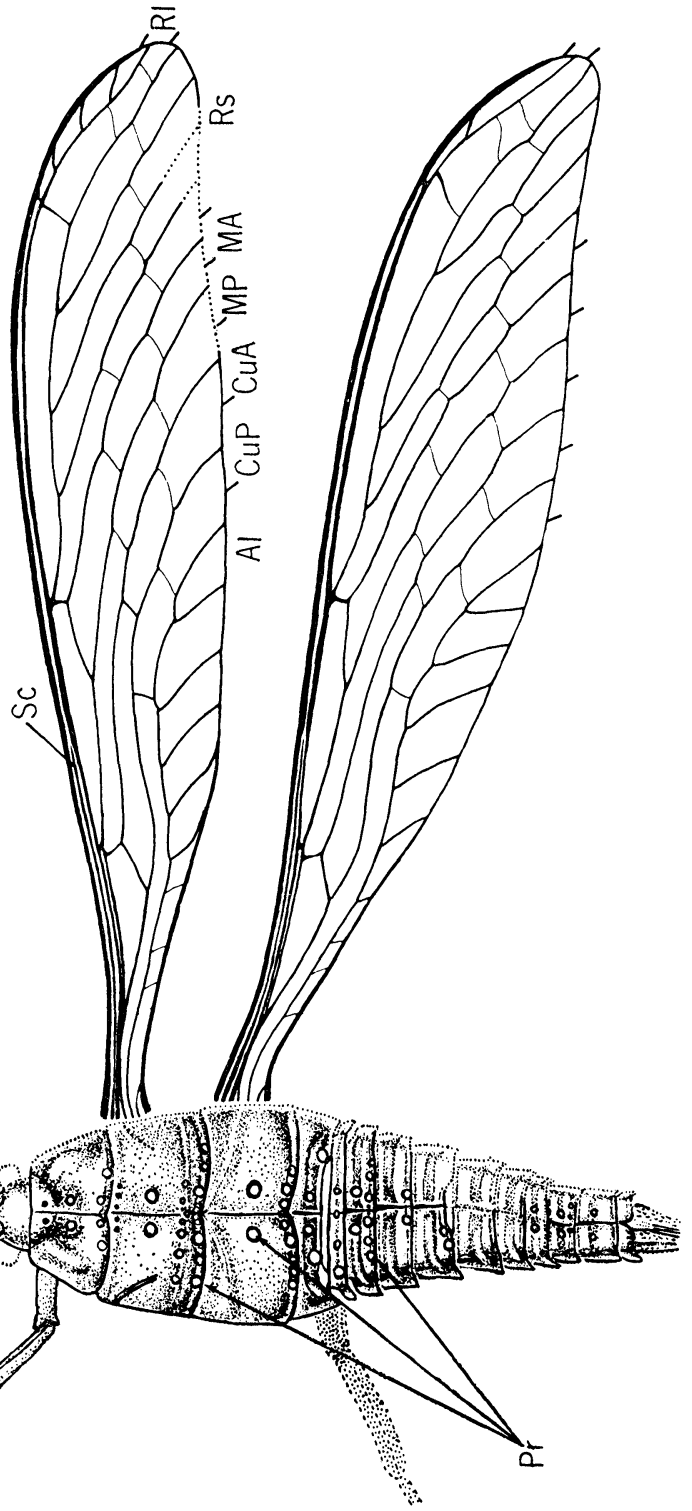

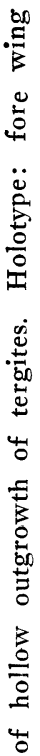

总.

$\|$ 㟧

ค. ำ

$\because$ 药

告

है छ

$\stackrel{2}{2}$

की

- है

는

总 
Carpenter (1947). A significant contribution to the morphology of the wings was published by Carpenter (1962). Until now, the family has been based only upon isolated, more or less fragmentary wings.

The following introduces certain characteristics of body structures and some additional features of wing morphology, based upon 5 new specimens from the Lower Permian of Siberia and Czechoslovakia.

Wings subequal in length and shape, strongly petiolate, similar in venation; $\mathrm{C}$ flattened and wide, very close to $\mathrm{Sc}$; $\mathrm{Sc}$ distinguishable as a separate vein only in proximal part of the wing; $R_{1}$ contiguous with $\mathrm{C}$ and Sc except in the very distal part of the wing; RI with short terminal branches; Rs originating at about midwing, giving rise to 2-3 branches; $M$ very close to $R$ basally, diverging away from $R$ beyond the first quarter of the wing length; $M$ dividing into $M A$ and MP at variable level, but near to the origin of Rs; MA connected with $\mathrm{Rs}$ or $\mathrm{R}$ with a strong cross vein; $\mathrm{Cu}$ at the base fused with the stem of $\mathrm{M}$; $\mathrm{CuA}$ connected with the stem of $\mathrm{M}$ by a strong cross vein; 2 anal veins, AI long with a pectinate series of branches; A2 very short and simple; cross veins not numerous, usually arranged in 2 rows; veins and wing margin with rows of setal bases or sockets.

Body structures: head small, short and broad, with large projecting eyes; antennae long, composed of many cylindrical segments; maxillary palpi robust; prothorax trapezoidal; mesothorax and metathorax large in proportion to the rest of the body; legs of middle length, cursorial; abdomen relatively slender, tapering abruptly in the anterior part; females with II visible segments and protruding ovipositor; projections forming rows on the posterior margin of thoracic and abdominal segments; parallel, transverse rows of projections on abdominal terga and occasionally on thoracic segments; larger projections located in pairs in the central parts of the body segments.

The family Bardohymenidae is closely related by wing morphology to Protohymenidae (Carpenter, 1962), which turns out to be true also for the body. However, the wing venation is less advanced, possessing an MA which is not anastomosed with Rs, and a $\mathrm{CuA}$ free from M. Also the general form of the wings is less specialized, as the hind wings are almost equal to the fore wings, not reduced in length as in the Protohymenidae. The body in both families is much alike, possessing a large thorax and tapered abdomen. The bardohymenid body is, in relation to the wings, more heavy. Through the courtesy of Dr. Carpenter I was able to study Protohymen readi Carpenter (1933), Protohymen elongatus Carpenter (1930) and 
Pnotohymen permianus Tillyard (1924) for projections. In all three specimens the bases of projections are present and very similarily distributed as in Bardohymenidae. However, they merge with the uneven surface of the rock to such an extent that they would be undetectable unless a well preserved specimen, such as the type of $S$. sibiricus n.sp., were available for comparison. By delicate preparation of the surrounding matrix I was able to uncover remnants of projections ( $P$. readi, specimen 3257, Museum of Comp. Zoology, Harvard University; $P$. permianus, specimen 5053, Peabody Museum Yale University), which are prolonged and backwardly curved. This fact is very significant, because in Sylvohymen sibiricus n.sp. (Bardohymenidae) the projections continue into the covering matrix and cannot be followed.

The projections in Bardohymenidae and Protohymenidae are arranged in transverse rows. By position and distribution they are very similar to denticles in the transverse carinae of Odonata. In my opinion, these structures may be homologous. Besides, some anisopteran nymphs (for instance Erpetogomphus designatus, Gomphidae) Needham \& Westfall, I955, bear, on several abdominal terga, paired darker pits, located along the median line precisely like the bases of the large paired projections in Bardohymenidae and Protohymenidae. This similarity is suggestive of possible musculature inside the paired projections in Megasecoptera.

Genera included: Bardohymen G. Zalessky, I937 (Lower Permian, Barda River, U.S.S.R.) ; Sylvohymen Martynov, I94I (Lower Permian, Tshekarda, Siberia, U.S.S.R. and Lower Permian, Oklahoma) ; Calohymen Carpenter, 1947 (Lower Permian, Oklahoma); Actinohymen Carpenter, I962 (Lower Permian, Texas) ; Alexahymen n.g. (Lower Permian, Czechoslovakia).

\section{Genus Sylvohymen Martynov}

Sylvohymen Martynov, 1941: 10; Carpenter, 1947: 31; Carpenter, 1962: 37; Rohdendorf, 1962: 68.

Type species: Sylvohymen robustus Martynov, 1938 (OD).

This genus is based upon a distal part of a wing from the same locality (Tshekarda) as the presently described specimen of Sibiricus, n.sp., which is much more fully preserved. Carpenter ( I946, p. 3I, fig. 7) described S. ingens from the Lower Permian of Oklahoma, also based on a distal wing third. The apical parts of the wing in all three specimens resemble each other and the species cannot be separated generically as far as is presently known. Unfortunately, they can also hardly be separated from Bardohymen (this statement 


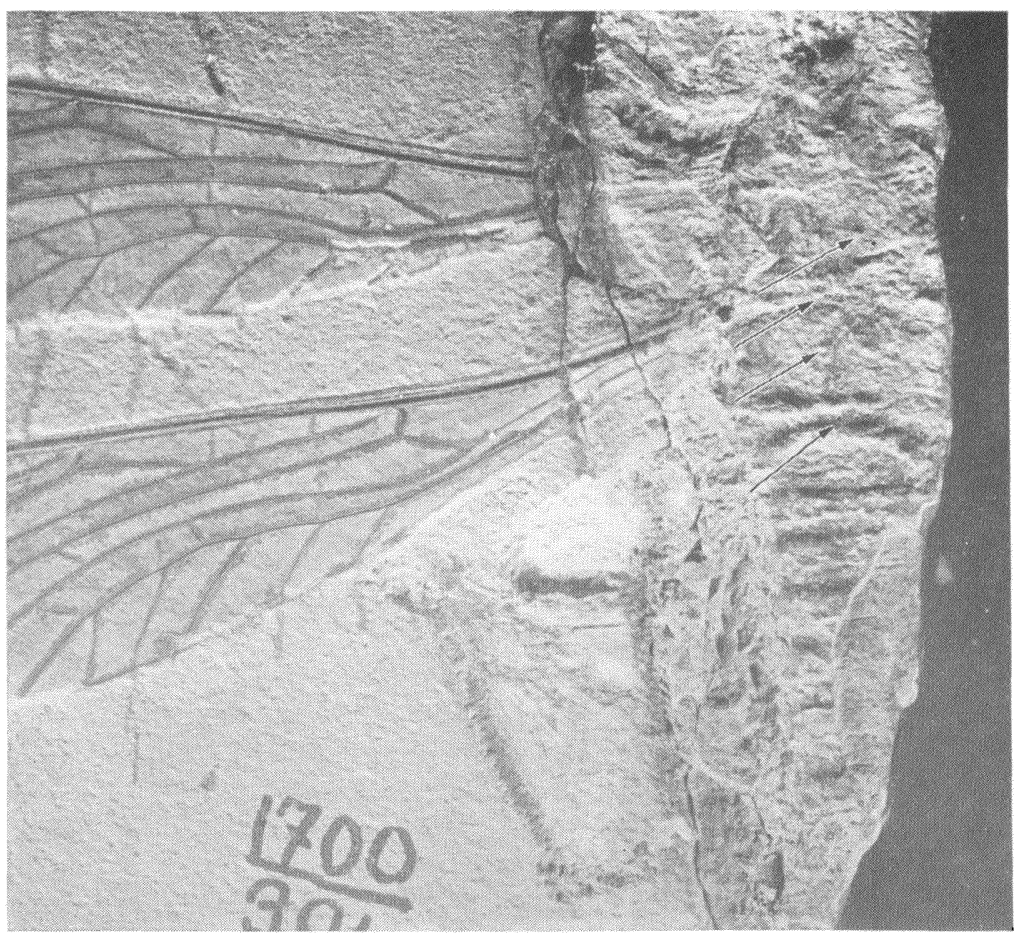

Plate 1

Sylvohymen sibiricus n.sp., obverse. The arrows point to the bases of the projections on the tergites. Lower Permian, Siberia.

is based on literature only) and further study of the original material might find the two genera synonymous.

Martyonv's reconstruction of Sylvohymen robustsus (I94I) showing $\mathrm{MA}$ anastomosing with Rs is obviously incorrect, as the connection of MA with $\mathrm{R}$ or Rs by means of a cross vein is characteristic for Bardohymenidae.

Wings long and slender, tapered rather abruptly in the basal third; hind wings slightly longer than fore wings, broader at about midwing; Sc recognizable only in proximal half of the wing; Rs with 3 main branches; Ar S-shaped; posterior margin in untapered part of wing almost parallel to the anterior margin.

Body structures: Prothorax with transverse elevations; metathorax broader than mesothorax; first abdominal segment strongly tapering; 
ovipositor in females stout, covered by hairs; projections probably maximally 14 in number in a row.

As shown previously by Martynov (I94I) and Carpenter (1947, p. 32), Sylvohymen is closely related to the type genus Bardohymen. The reconstruction of Bardohymen magnipennifer (G. Zalessky I937, p. 6o3, fig. I) is obviously incorrect for its cubital branches. By the structure of pterostigmal area the genus Sylvohymen is related to Alexahymen n.g., which differs in having a relatively shorter and broader wing with concave posterior margin, small rs area and $\mathrm{AI}$ parallel with posterior margin.

Species included: Sylvohymen robustus Martynov, 1938 (Lower Permian, Oklahoma); Sylvohymen sibiricus n.sp. (Lower Permian, Tshekarda, Siberia).

\section{Sylvohymen sibiricus n.sp. ${ }^{1}$ \\ Figure I, plates I and 2}

This species is based upon an obverse and reverse of a female with two complete wings and damaged lateral part of body. The thorax and the abdomen are preserved on the dorsal side, while the head presents a composite of dorsal and ventral surface showing bases of stout palpi. The projections, if only the obverse were known, give the appearance of stout tubercles. In the reverse, however, they continue like hollow tubes into the matrix.

For preparing the illustration, both obverse and reverse parts of the specimen were used.

Wings slightly subequal, the hind pair being longer and broader at about midwing; color markings missing; fore wing length $50 \mathrm{~mm}$, maximum width 9.I $\mathrm{mm}$, almost equally broad except for the tapered proximal third; anterior margin slightly convex; $\mathrm{C}$ bordering the whole wing; apex bent backward and almost pointed; $\mathrm{R}_{I}$ apically diverging to some extent, with I-3 terminal twigs; Rs with 3 simple long branches; AI S-shaped with a row of about 9 branches; cross veins about $I 8$ in number; cross vein between $R_{I}$ and $R s$ forming a heavy bar, thickened at its costal end; hind wing length $5 \mathrm{I} \mathrm{mm}$, maximum width $9.7 \mathrm{~mm}$, broadest at the mid-wing; hind wing narrowing proximally less abruptly; anterior margin somewhat straighter; $\mathrm{R}_{\mathrm{I}}$ apically less diverged away from the anterior margin, with only I twig.

${ }^{1}$ This remarkable specimen was turned over to me for study by the courtesy of Dr. B. B. Rohdendorf, the head of the Paleoentomological Department of the Paleontological Institute of the Academy of Sciences in Moscow, for which I express my sincere gratitude. 


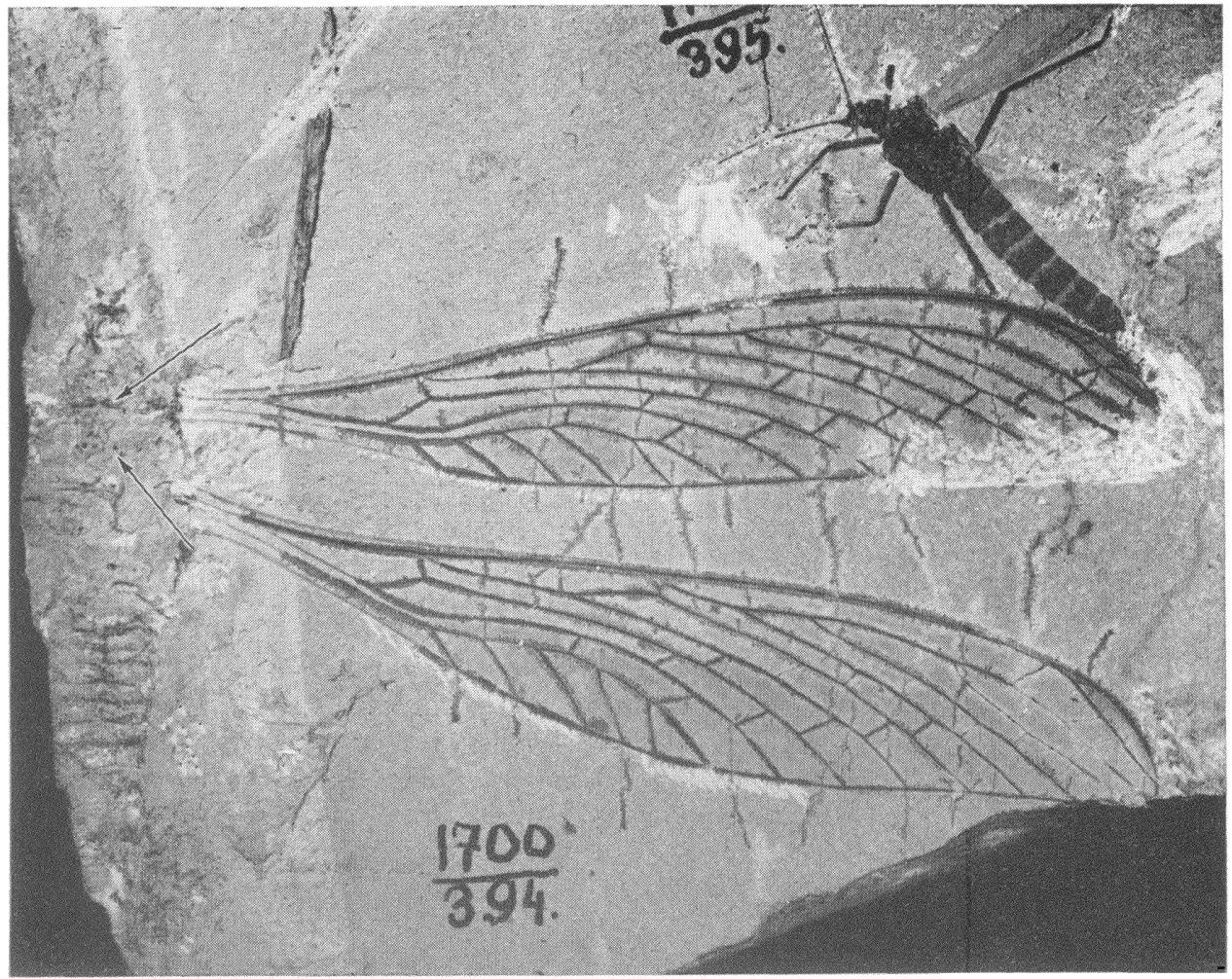

Plate 2

Sylvohymen sibiricus n.sp., reverse. The veins are secondarily colored by manganese. Arrows point to hollow continuations of projections into the matrix. Lower Permian, Siberia. 
Body structures: Length of head $1.8 \mathrm{~mm}$, width about $3.6 \mathrm{~mm}$; preserved length of antennae $9 \mathrm{~mm}$, antennae composed of numerous cylindrical segments; segments of maxillary palpi striated, preserved segment length I.I $\mathrm{mm}$, width $0.8 \mathrm{~mm}$; median line running along the whole body; prothorax length $4 \mathrm{~mm}$, maximum width $8 \mathrm{~mm}$, provided with two obliquely oriented longitudinal elevations and one elevation located anteriorly and centrally; mesothorax length 4.I mm, probable width $8.8 \mathrm{~mm}$; metathorax length $4.2 \mathrm{~mm}$, maximum width probably $9.2 \mathrm{~mm}$; legs covered by setae; front tibia length $38 \mathrm{~mm}$; hind tibia length about $50 \mathrm{~mm}$; abdomen length $14.5 \mathrm{~mm}$, maximum width $9.4 \mathrm{~mm}$; abdominal segments unequal, length of segments as follows: Ist $2 \mathrm{~mm}$; 2nd $0.8 \mathrm{~mm}$; 3rd I. $3 \mathrm{~mm}$; 4 th I. $7 \mathrm{~mm}$; 5 th 2 $\mathrm{mm}$; 6th $2 \mathrm{~mm}$; 7 th $0.5 \mathrm{~mm}$; 8th I mm; 9th I mm; IOth $1.6 \mathrm{~mm}$; I I th $0.5 \mathrm{~mm}$; each abdominal segment but the II th has a transverse flat topped ridge; I I th segment divided by a deep incision into two lobes; ovipositor stout, reaching much beyond the end of the body, covered by dense stiff hairs oriented anteriorly.

Projections: Two stout projections located in the central part of each body segment except the IIth; prothorax with an additional pair of projections anteriorly and with about 8 projections along the posterior margin; mesothorax with a row of small projections parallel and near to the anterior margin and with double row of stouter projections on the posterior margin; metathorax with a series of stout projections on posterior margin; abdominal segments with a row of stouter projections on the flat topped ridge and another row of smaller projections bordering the posterior margin; I Ith segment with only the posterior row of minute projections.

Holotype: No. I 700/394, Paleoentomological Department, Paleontological Institute of the Academy of Sciences in Moscow. Collected in Lower Permian deposits of Tshekarda, Siberia.

The preservation of the holotype is very good, particularly because the veins of the wings have been secondarily penetrated and colored by manganese, which enters also the minute transverse cracks. The body is not fully flattened. The abdomen especially is preserved in its original convexity. Some of the bases of the projections are well preserved and only those are introduced in figure I, marked as circles, as they actually appear. The projections were undoubtedly growing out from the tergites in regular rows, but since the surface of the body is uneven, they cannot be distinguished from the irregularities of the matrix. The actual length of the projections could not be followed as they continue inside the reverse of the fossil under an acute angle with the body. Their position, however, indicates that 
they have been sclerotized. In analogy to the closely related Protohymenidae, it is probable that the projections were slightly curved and at least several millimeters long.

Genus Alexahymen, new genus

Type species: Alexahymen maruska n.sp., Lower Permian of Moravia.

This genus includes one species, represented by 3 incomplete wings.

Wings shorter than in the related genus Sylvohymen, broadest behind the midwing, tapering gradually towards the base; Sc distinct to about two thirds of the wing length; $\mathrm{R}_{\mathrm{I}}$ diverging apically slightly from the anterior margin; Rs with two short branches; Ar parallel with the posterior margin; posterior margin slightly concave.

Alexahymen differs from other genera of the family Bardohymenidae in its relatively short and broad, gradually tapering wings, posterior margin concavely shaped, AI parallel with the posterior margin and sending off a series of numerous twigs, and small rs area.

Species included: Alexahymen maruska n.sp. (Lower Permian, Obora, Moravia).

\section{Alexahymen maruska n.sp.}

Figure 2, 3, 4

Derivatio nominis: In honor of Mrs. Maruska Alexová, who generously gave support and encouragement to workers at the Obora locality for ten years.

This species is based upon the holotype, represented by a wing without the proximal part, and by two additional, isolated, equally damaged wings. With regard to the close similarity between the fore and hind wings in Bardohymenidae, the position of wings in the pair can be only inferred. However, from analogy with Sylvohymen sibiricus, the only bardohymenid with both wings in situ, it seems that the hind wings in this family tended to have a straighter anterior margin and more concave posterior margin. Consequently, the holotype (fig. 2) and specimen 2/1972 (fig. 3) are represented probably by the hind wing, while specimen $3 / 1972$ (fig. 4) is more likely the fore wing.

Color markings missing; total wing length about $33-36 \mathrm{~mm}$, maximum width $8.7-9.9 \mathrm{~mm}$; anterior margin slightly convex in the distal part; $C$ bordering the wing; apex more or less pointed; $\mathrm{R}_{\mathrm{I}}$ with 4-5 very short terminal twigs; Rs branches short; $A$ I sending off 6 branches; cross veins I5-16 in number, mostly in double row.

Material: Holotype No. I/I972 (obverse and reverse probably of hind wing); specimen No. 2/1972 (obverse and reverse probably of 


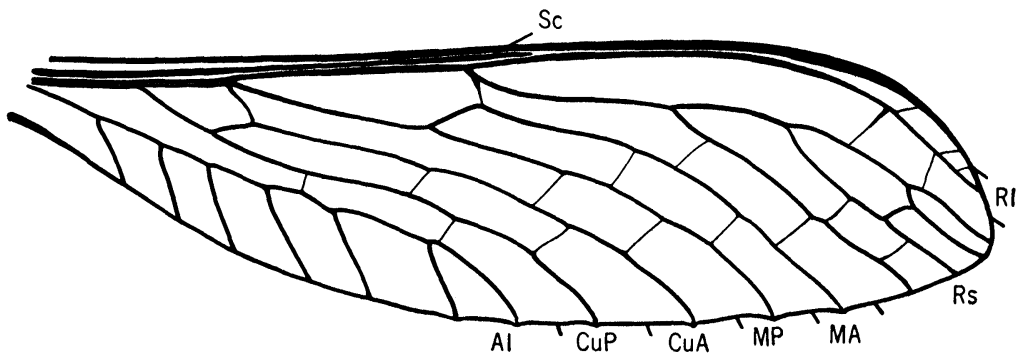

Figure 2. Alexahymen maruska n.sp.; hind wing: length $30 \mathrm{~mm}$, width $9 \mathrm{~mm}$. Holotype. Lower Permian of Czechoslovakia.

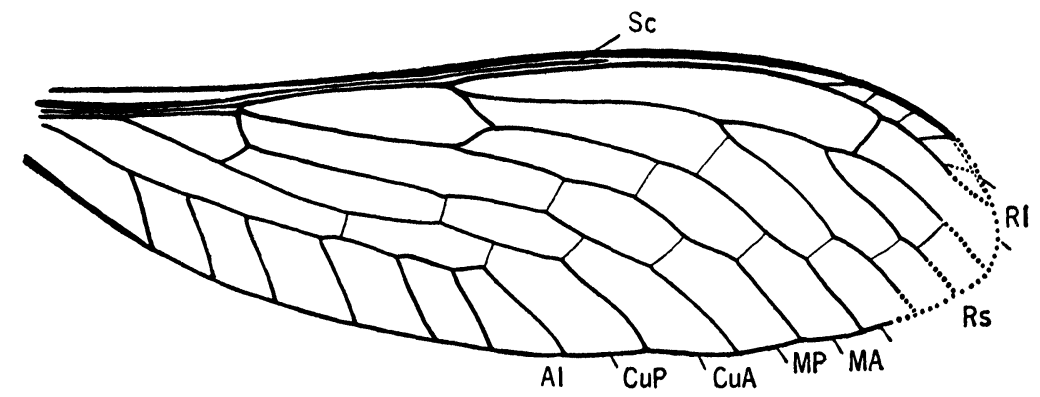

Figure 3. Alexahymen maruska n.sp.; hind wing: length $31.8 \mathrm{~mm}$, width, $9.9 \mathrm{~mm}$. Specimen 2/1972. Lower Permian of Czechoslovakia.

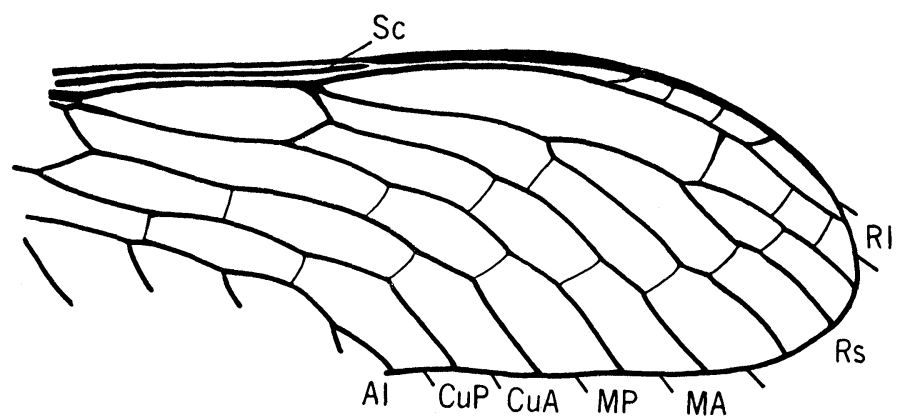

Figure 4. Alexahymen maruska n.sp.; fore wing: length $23 \mathrm{~mm}$, width $8.7 \mathrm{~mm}$. Specimen 3/1972. Lower Permian of Czechoslovakia. 
hind wing) ; specimen No. 3/1972 (obverse and reverse probably of fore wing) ; Paleontological Institute of Charles University, Prague, Czechoslovakia. Collected in the Lower Permian deposits near Obora, Moravia.

All three specimens of Alexahymen maruska carry the details of venation, described by Carpenter (1962, p. 38-39) in Actinohymen russeli, namely flattened $\mathrm{C}$, widening distally beyond the end of $\mathrm{Sc}$; and $\mathrm{C}, \mathrm{Sc}, \mathrm{R}-\mathrm{RI}_{\mathrm{I}}$ around midwing touching each other. The cross vein rs-r I forms a heavy bar widened at its costal end in the holotype and specimen $3 / 1972$. In the specimen $2 / 1972$ it is an average, though thick cross vein.

The posterior margin in the holotype is formed in a different way, perhaps as individual variation. It is convexly curved in between the branches of $A_{I}$, media and cubitus, so that the tips of the branches protrude not unlike the fingertips in a bat wing. A similar phenomenon is indicated in Moravohymen vitreus n.sp. of the related family Moravohymenidae.

\section{Type genus: Moravohymen n.g.}

\section{Moravohymenidae, new family}

This family is based upon a fragment of a single wing (probably hind wing), which seems to combine the features of Bardohymenidae with those of some megasecopterid families of Commentry, France (Carpenter, 195I).

Wings broadest at the beginning of the apical third, tapering gradually proximally; Sc remote from the anterior margin and terminating freely in the subcostal area well before apex; RI remote from Sc, not diverging apically from the posterior margin; MA connected with $R$ or with the very origin of $R$ s by a cross vein; stem of $M$ either close or fused with R; AI not parallel with the posterior margin, sending off few irregular branches; cross veins arranged into irregular rows and partly sigmoidal; row of cross veins in $\mathrm{r}$ I-rs area; veins and wing margin provided by setae.

The family Moravohymenidae has very gradually tapering wings with maximum width shifted to the distal third. MA is connected with $\mathrm{R}$ or $\mathrm{Rs}$ very much as in Bardohymenidae. The arrangement of the rest of the veins and sigmoidal cross veins reminds one more of some Upper Carboniferous Commentry families such as Mischopteridae, Sphecopteridae and Corydaloididae.

Genus included: Moravohymen n.g. (Lower Permian, Czechoslovakia). 


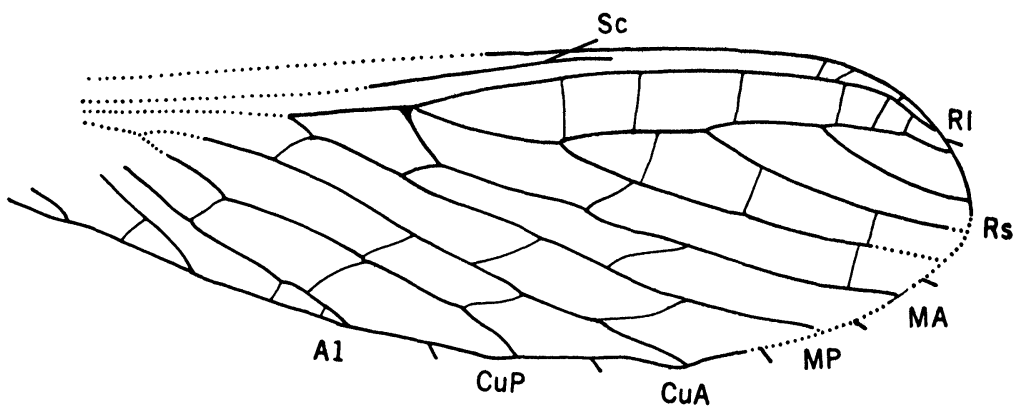

Figure 5. Moravohymen vitreus n.sp.; hind wing: length $21 \mathrm{~mm}$, width $6.9 \mathrm{~mm}$. Holotype. Lower Permian of Czechoslovakia.

\section{Genus Moravohymen new genus}

Type species: Moravohymen vitreus n.sp., Lower Permian of Moravia.

Wings rather small, narrow in the proximal half, broad in the distal half; $\mathrm{C}$ not flattened; $\mathrm{Sc}$ rather a thin vein; $\mathrm{R}_{\mathrm{I}}$ sending off several short twigs apically; Rs originating shortly behind midwing; Rs with 3 branches; branches of $\mathrm{M}$ and $\mathrm{Cu}$ simple; Ar remote from the posterior margin, anal branches irregular and rather long; cross veins arranged by two or three in the posterior part of the wing.

Species included: Moravohymen vitreus n.sp. (Lower Permian of Obora, Moravia).

\section{Moravohymen vitreus n.sp.}

Figure 5

This species is based upon an obverse and reverse of a wing with damaged proximal part. According to the concave shape of the posterior margin it might be a hind wing.

Wing fragment: length $2 \mathrm{I} \mathrm{mm}$, maximum width $6.9 \mathrm{~mm}$; C, Sc and $R_{I}$ distally much thinner veins than in Bardohymenidae; the membrane in the pterostigmal region probably sclerotized; RI sending off 3 terminal twigs to C; rI-rs area broad, with 6 weak cross veins; Rs branches occupying a considerably large area; cross vein connecting MA with $\mathrm{R}$ at the origin of $\mathrm{Rs}$ is a heavy bar, thickened at its costal end; cross veins in medial area and cubital area slightly sigmoidal; posterior margin with small convex bends in between the ends of median and cubital branches.

Holotype: No. 4/1972 (obverse and reverse probably of hind wing); Paleontological Institute of Charles University, Prague, 


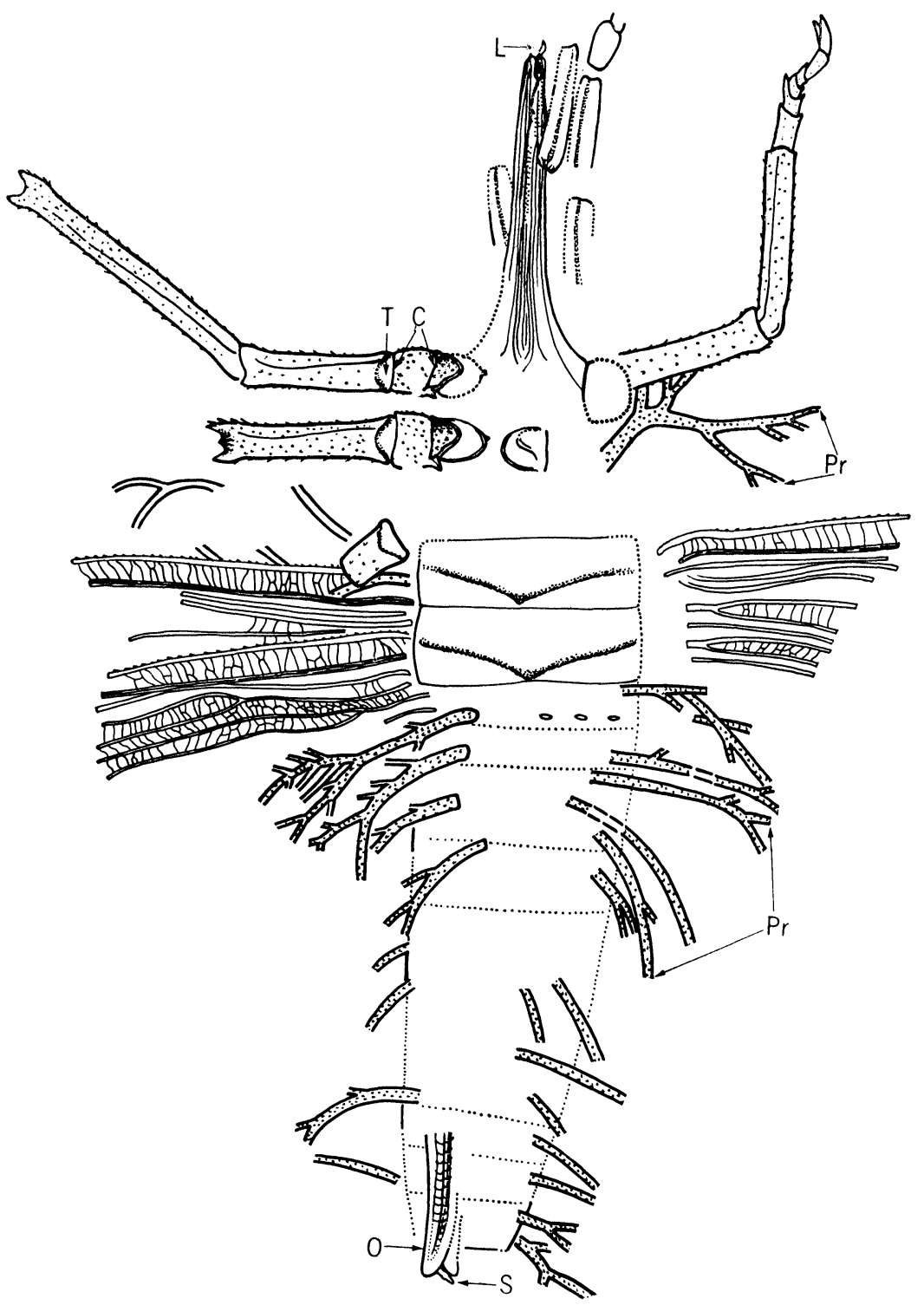

Figure 6. Monsteropterum moravicum n.sp.; $\mathrm{C}=\operatorname{coxa} ; \mathrm{L}=$ lacinia; $\mathrm{O}=$ ovipositor; $\mathrm{Pr}=$ projections provided with setae; $\mathrm{S}=$ stylus; $\mathrm{T}=$ trochanter. Original, ventral view. Lower Permian of Czechoslovakia. 
Czechoslovakia. Collected in the Lower Permian deposits near Obora, Moravia.

\author{
Order Palaeodictyoptera \\ Family Homoiopteridae Handlirsch \\ Genus Monsteropterum, new genus
}

Type species: Monsteropterum moravicum n.sp., Lower Permian of Moravia.

This remarkable fossil with fragmentary wings would hardly warrant formal description because the classification of the order is based upon the wing venation. However, the specimen shows the inner structure of the sucking mouth parts, the ventral attachment of the legs to the body, the branched projections of terga with preserved surface and an ovipositor provided by styli. Since this insect is of unusual interest, generic and specific names are being assigned.

Though the wings of the specimen are fragmentary, there is no doubt about referring them to the family Homoiopteridae, according to following characteristic features (Kukalová 1969, p. 440) : stem of main veins with a bend in the basal third of the wings; $\mathrm{CuA}$ and $\mathrm{CuP}$ parallel to each other; numerous, irregular and of ten connected cross veins. Of the genera included, Boltopruvostia Strand, I929 is probably the nearest related genus. From this, Monsteropterum differs in lacking the sclerotized strip and tubercles strengthening the costal area and in the more proximal division of $M$. The new genus is the first Permian representative of this rather primitive family and extends its occurrence from Upper Namurian to Lower Permian.

\title{
Monsteropterum moravicum n.sp.
}

Figures 6, 7, 8, 9, Io; plate 3

The body is a composite of ventral surface and inner structures, which were uncovered by preparation at different levels. With regard to the complexity of the composite, preservation must be discussed next.

The body was preserved while lying on its dorsal side. It was much decomposed before being covered by sediment. The maxillary palpi disintegrated into single segments, which were partly displaced. The legs with some parts of the sterna were shifted towards the head. Valves of the ovipositor were split open. Only legs, wings, and one segment of maxillary palpi show the natural ventral surface. The beak split unevenly along the median plane, showing the inner side of two mandibular stylets and a small fragment of the distal end of one maxillary stylet (fig. 7-Ma). Meso- and metathorax expose the inner surface of the terga. The abdomen split between the sternal 


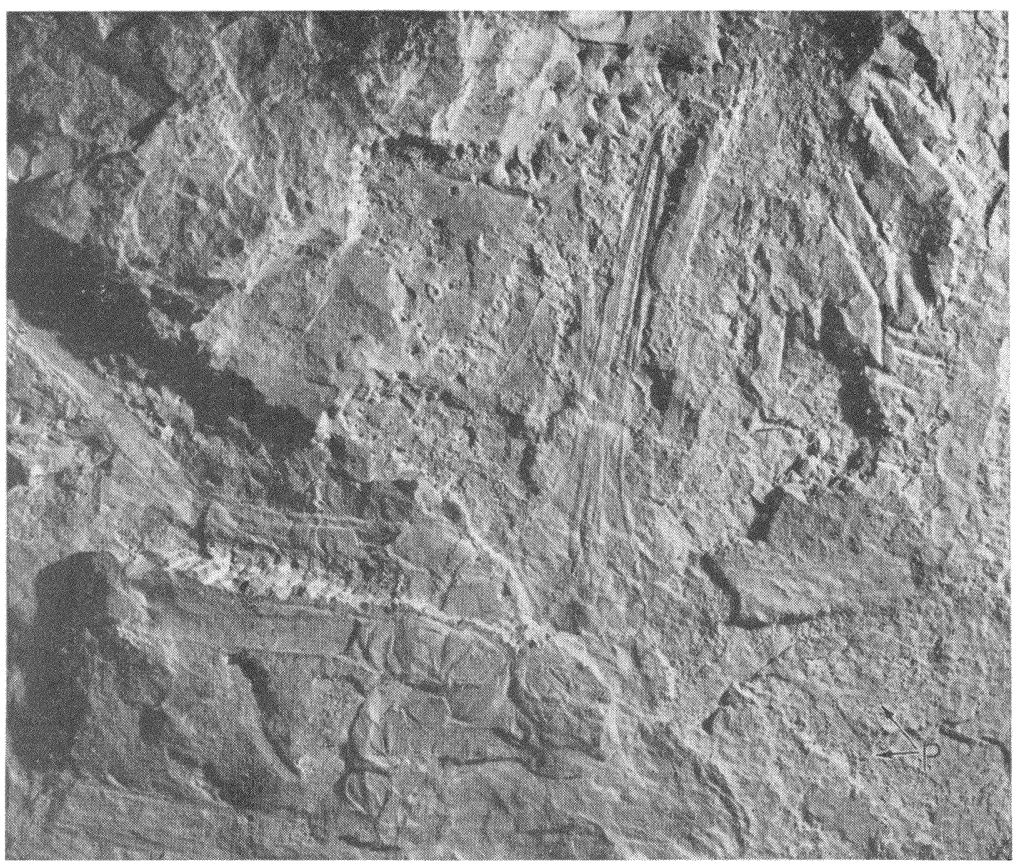

Plate 3

Monsteropterum moravicum n.sp. Ventral side of the body showing long beak, attachment of legs to the body and tergal projections (P). Lower Permian, Czechoslovakia.

and tergal elements and is vaguely preserved. It was partly removed to uncover the projections.

Head structures: The character of the palaeodictyopteran mouthparts, which are elongated into a beak consisting of stylets of mandibles and maxillae, have been described in more detail by Crampton (I927) and by Laurentiaux (1952, I953). However, there was no evidence about the arrangement of the stylets. Only recently Carpenter and Richardson (I97I, p. 280) described a section of the beak in a strikingly unusually preserved specimen. The pair of some-

Figure 7. Enlarged beak of Monsteropterum moravicum n.sp., ventral view. The beak split unevenly along median plane between two pairs of stylets. $A-B=$ section of the beak figured on the block diagram in fig. $8 ; \mathrm{E}=$ oval elevation; $\mathrm{L}=$ lacinia $; \mathrm{Ma}=$ fragment of the maxillary stylet represented by the apical part of galea; $\mathrm{Md}=$ natural inner surface of mandibular stylet where it contacts maxillary stylet; $\mathbf{P}=$ crescentshaped pit. Lower Permian of Czechoslovakia. 


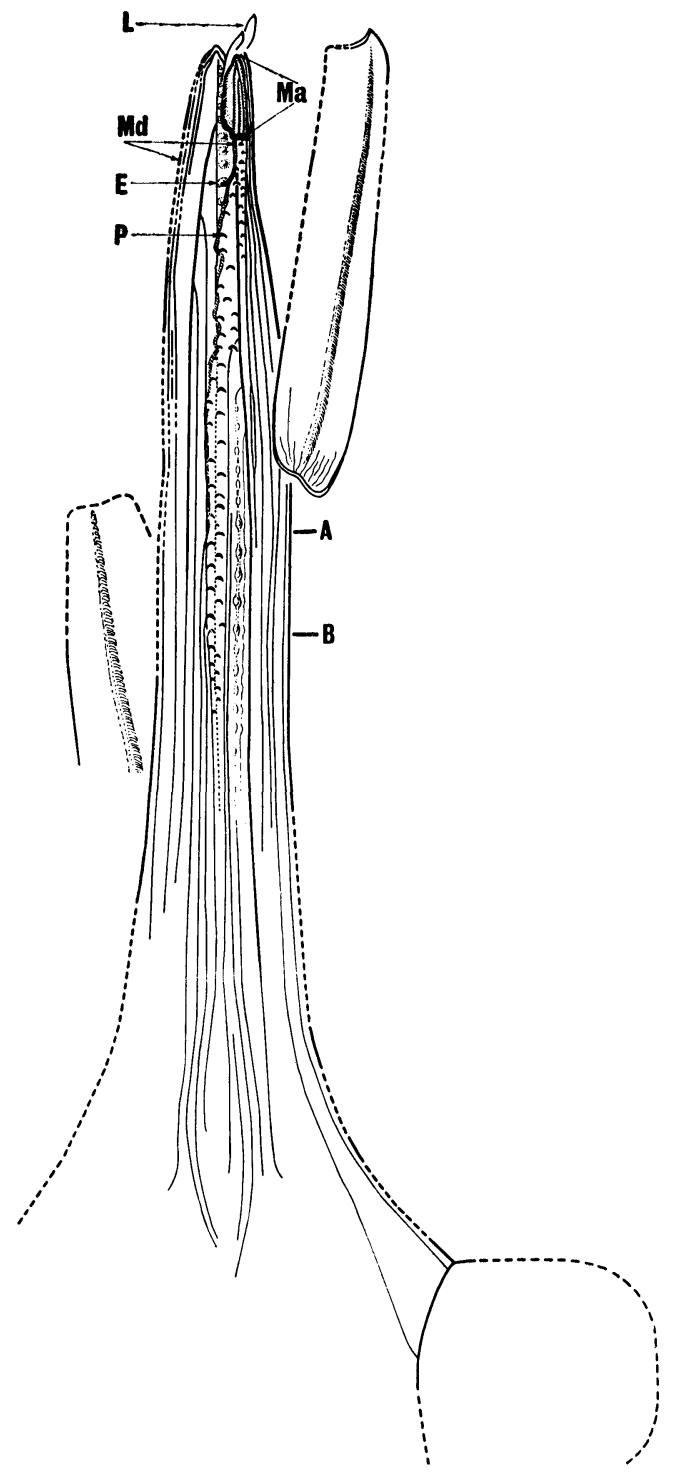


what larger mandibles is located anteriorly from the maxillae and there is the fifth stylet, probably derived from the hypopharynx, between the maxillae and slightly more posterior.

The arrangement of the stylets in Monsteropterum moravicum fully confirms the conclusion of Carpenter and Richardson. The pair of mandibles is superimposed, and slightly longer than the pair of maxillae. The mandibular stylets in all probability partly overlap each other along the inner margin, because the undisturbed width of the left mandibular stylet (fig. $7-\mathrm{Md}$ ) extends much beyond the ideal median line. The same madibular stylet probably exposes in this part (fig. 7-Md) its natural inner surface where it contacts the maxillary stylets. It is provided by alternating ridges and grooves (fig. 8-R, G) probably enabling firmer connection in between stylets and strengthening the long stylets.

The rest of the beak (more proximal and right part in fig. 7) shows the inside surface of the cavity in the mandibular stylets. It seems certain that the mandibles were hollow, as in Recent dragonflies (P. S. Corbet, in litt.). The mandibles of other extant insects are mostly solid except for occasional cavities and canals containing nerves for sensillae and haemolymph. The hollow nature of the elongated mandibles of the Palaeodictyoptera may be explained as a means of reducing the mass of the head. This assumption seems an acceptable solution for the mechanical problems of flight engendered by the considerable weight of the head when compared to the rest of the body.

In the cavity inside the mandibular stylets, there are 5 rows of deep crescent-shaped pits (fig. 7-P; 8-P) and oval elevations (fig. 7-E; $8-\mathrm{E}$ ). They form continuous rows and seem to belong to a single structural unit, which is a series of short, peg-shaped, perpendicularly oriented pillars, supporting the long hollow mandibular stylets from inside. This assumption is based mainly on the fact that the second row of crescent-shaped pits (fig. 7-P) passes distinctly under the layer $\mathrm{Md}$ (fig. 7), which is the natural surface of the mandible in contact with the maxillary stylet. On the Md layer the pit row continues in the form of oval elevations (fig. $7-\mathrm{E}$ ).

The left maxillary stylet is completely missing; the right is preserved only by the fragment of distal end (fig. 7-Ma). However, it provides information on the morphology of the mouthparts in Palaeodictyoptera: the maxillary stylets were located under the mandibular stylets (in fig. 7 reversed because of the ventral view of the beak); they were distinctly shorter than the mandibles; they were 


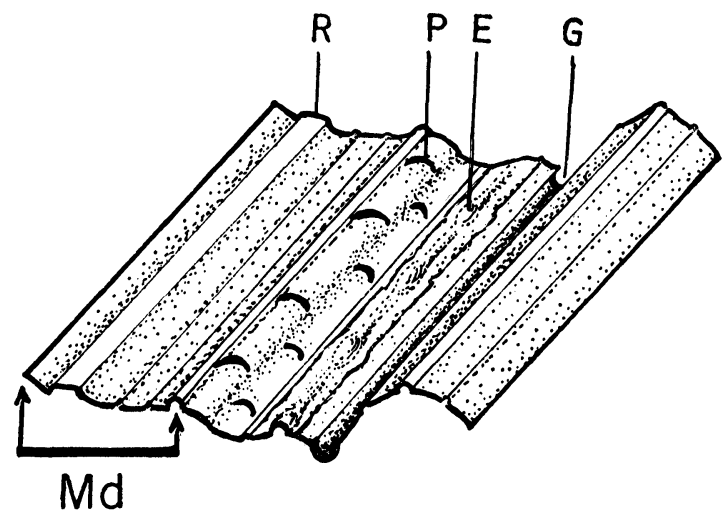

Figure 8. Blockdiagram representing section of the beak between $A$ and $B$ (see fig. 7 ), in ventral view. Left part ( $\mathrm{Md}$, indicated by bracket) is probably the natural inner surface of the mandibular stylet where it contacts maxillary stylet. Right part is a composite of several inner surfaces of the hollow mandible. Oval elevations (E) and crescent-shaped pits (P) are probably opposite ends of short perpendicular pillars, which crossed the mandibular cavity and supported it from inside. Original. Lower Permian of Czechoslovakia.

divided into more robust galea and thin, protruding lacina (fig. $7-\mathrm{L}$ ); the lacinia is located at the inner margin and underneath the galea; the lacinia extends beyond the beak and has two inward curved apical lobes; the external surface of the maxillae carried fine ridges. ${ }^{2}$

Because the beak is split along the median plane, it presents an uniquely favorable occasion to study the inner structure. However, it gives little reliable information about the character of the food canals. The transverse section of the beak (fig. 8 ) is actually a composite of several inner surfaces of the mandibles, all of them carrying alternating grooves and ridges, and is slightly distorted by an oblique pressure. Because of the uneven level of splitting and slight deformation during fossilization, the food canals are not clearly distinguishable.

The maxillary palpi are robust and overlap with the beak (fig. 6). All segments carry a flat-topped longitudinal ridge. The surface is covered with a fine rugosity and with occasional irregular grooves.

\footnotetext{
${ }^{2}$ The more perfect preservation of the beak in Monsteropterum moravicum brings an explanation of the "protruding needle-like tips" in the beak of Mecynostoma dohrni (Palaeodictyoptera, Mecynostomatidae, Kukalová 1969 , p. 210, fig. 28). The protruding structures are undoubtedly also laciniae extending beyond the superimposed pair of mandibles.
} 


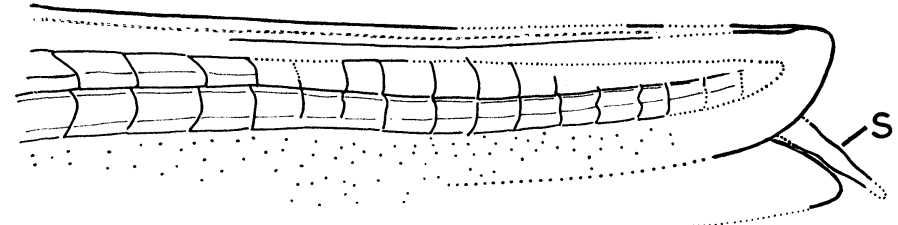

Figure 9. Monsteropterum moravicum n.sp. Enlarged ovipositor with striations, scattered setae and stylus (S), resembling the endophytic ovipositor of Odonata. Lower Permian of Czechoslovakia.

The legs expose their natural ventral surface. The coxae are short and conically truncate (fig. 6-C; fig. IO-C). Proximally are adjoined two additional circular structures, which perhaps represent the katapleuran ring separated by a sigmoidal paracostal suture from the anapleuran ring (fig. Io-K, S, A). The trochanter (fig. 6-T; fig. Io$\mathrm{T}$ ) is grown together with the femur and is preserved only as a triangular swelling. The tibia is slightly longer than the femur. The tarsus is five-segmented, with the 3 rd and 4th segments distinctly shorter than the remaining ones. The praetarsus bears a pair of lateral claws. The legs are covered by scattered setae and a granular rugosity.

The mesothorax and metathorax are about equal in size, with a broad V-shaped ridge.

The ovipositor has striations (fig. 9) similar to those in some other Palaeodictyoptera (Kukalová in Carpenter, 1971, p. 124I, fig. 6) and in the related order Diaphanopterodea (Kukalová 196r, p. 293, fig. 2). The ovipositor carries scattered, proximally oriented, setae. With this specimen styli are recognized for the first time for the order Palaeodictyoptera. Within the extant insects, styli on female genitalia are known in the adult stage only in one order, the Odonata, in which they arise from the second coxopodite. Also, the general appearance of the ovipositor is very much like the endophytic ovipositors of some Odonata.

The projections (fig. 6-P) are long and very branched, apparently much more than preserved in the fossil. They have scattered setae and their surface is finely rugose. The sockets of the setae are deeply incised and their density is about equal to that on the legs. The setae increase in number towards the ends of the branches. The projections are stiffly backwardly curved and were undoubtedly sclerotized.

Previously, I have been able to study projections in four families of the order Megasecoptera. In all the projections were simple, un- 

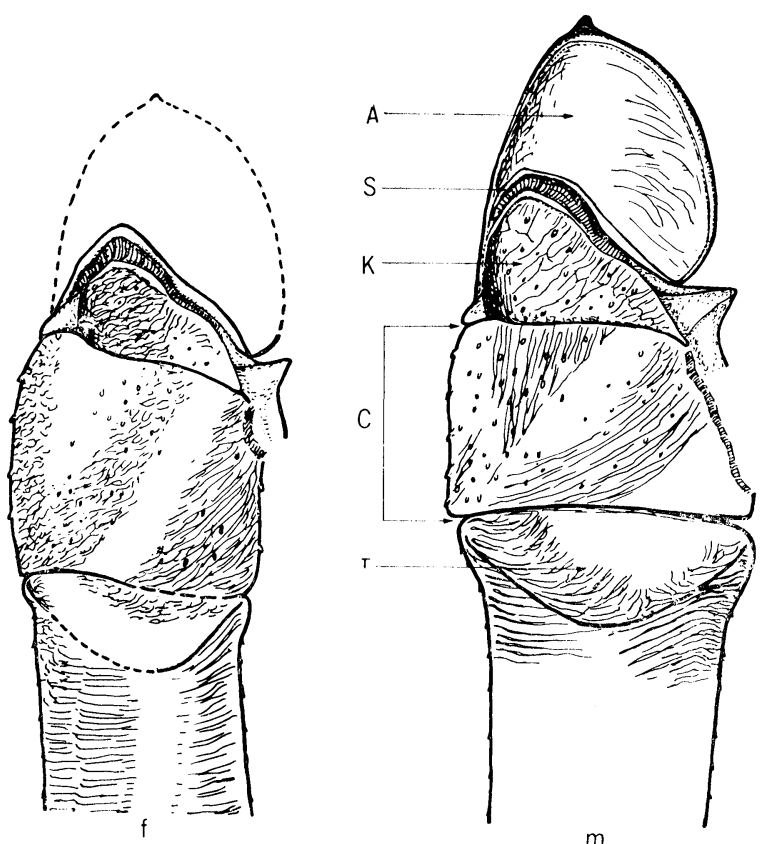

Figure 10. Monsteropterum moravicum n.sp. Enlarged proximal parts of left front leg and left middle leg. $\mathrm{A}=$ anapleuran ring; $\mathrm{C}=$ coxa; $\mathrm{f}=$ front $\operatorname{leg} ; \mathrm{K}=$ katapleuran ring $; \mathrm{m}=$ middle leg $; \mathrm{s}=$ sigmoidal paracostal suture; $\mathrm{T}=$ trochanter. Original, ventral view. Lower Permian of Czechoslovakia.

branched outgrowth of the terga. The specimen here described is the first example with projections in the order Palaeodictyoptera and at the same time the first one to show branching. Additional examples should be expected within Palaeodictyoptera, even though their occurrence probably was not as common as in the Megasecoptera.

Dimensions: Beak length $20 \mathrm{~mm}$, width at the middle $2 \mathrm{~mm}$; lacinia length $\mathrm{I} \mathrm{mm}$; complete segment of maxillary palpus length $8 \mathrm{~mm}$; legs I. pair: coxa length $2.8 \mathrm{~mm}$, femur length $10.2 \mathrm{~mm}$, tibia length I $2.2 \mathrm{~mm}$, tarsus length $8.2 \mathrm{~mm}$, praetarsus length 2.6 $\mathrm{mm}$; II. pair: coxa length $2.4 \mathrm{~mm}$, femur length $\mathrm{I} 2 \mathrm{~mm}$; mesothorax length $4.8 \mathrm{~mm}$, width $14.6 \mathrm{~mm}$; metathorax length $4.8 \mathrm{~mm}$, width I $4.6 \mathrm{~mm}$; abdomen total length about $38 \mathrm{~mm}$; fragment of ovipositor length $9.7 \mathrm{~mm}$; longest fragment of abdominal projection length $16 \mathrm{~mm}$; maximum width $0.8 \mathrm{~mm}$. 
Original: No. 5/1972 (obverse and reverse of the body and basal parts of wings; separately reverse of the right front leg); Paleontological Institute of Charles University, Prague, Czechoslovakia. Collected in the Lower Permian deposits near Obora, Moravia.

\section{Summary}

Megasecoptera and Palaeodictyptera, two of the three extinct paleopterous haustellate insect orders related to extant Ephemeroptera and Odonata, were found to carry fringe-like projections on the thorax and abdomen. Both orders include mostly large to very large insects with good flying ability, which held the wings outstretched when resting. The nymphs were terrestrial, probably arboreal, and had articulated wing pads which were oriented obliquely backwards (Carpenter and Richardson, 1968).

The projections are hollow outgrowth of the terga, forming usually regular rows along the posterior margin or occasionally also on the nota. They are more or less sclerotized, protruding up and backwards from the body. The surface is rugose and with scattered tactile setae. The projections are simple or richly branched and vary from short to very long. They occur in both adults and nymphs. As far is known, their morphology is characteristic for separate families.

Now, the projections are known in Mischopteridae, Aspidothoracidae, Corydaloididae, Brodiidae, Protohymenidae and Bardohymenidae in the order Megasecoptera and in Homoiopteridae in the order Palaeodictyoptera. In their location, they are homologous with the dentation on the transverse abdominal carinae, present in all extant Odonata and with paired pits on abdominal terga in nymphs of Gomphidae.

Since the projections are obviously a unique and isolated character, their function in two extinct Paleozoic orders is obscure. From the morphology it might be assumed that they were at least to some extent movable and were provided with mechanical sense organs.

The following additional characters have been added to the knowledge of Palaeodictyoptera:

The beak consists of stylets of mandibles and maxillae, the pair of mandibles being longer and superimposed. Each maxilla is divided into a robust galea and thin lacinia, located at the inner margin and underneath the galea. The lacinia has two, inwardly curving apical lobes and extends beyond the beak. Mandibular stylets partly overlap each other along the inner margin. On contact with the maxillae, 
they have alternating ridges and grooves, enabling firmer connection. The mandibular stylets are hollow and the cavity is crossed by rows of perpendicularly oriented pillars, providing additional mechanical support.

The legs have short, conically truncate coxae. Proximally, on the ventral side, there are two circular structures, which perhaps represent the katapleuran ring separated by a sigmoidal paracostal suture from the anapleuran ring. The trochanter is triangular, grown together with the femur as in Odonata.

The ovipositor is provided by styli as in extant Odonata.

\section{Literature Cited}

BRONGNIART, C.

1885. Les insectes fossiles des terrains primaires. Bull. Soc. Rouen: 50-68.

1885. Die fossilen Insekten der primären Schichten. Jahrb. k.k. Geol. Reichsanstalt, $35(4)$ : 649-662.

1890. Note sur quelques insectes fossiles du terrain houiller qui présentent au prothorax des appendices aliformes. Bull. Soc. Philomatique de Paris, 8 ser. $2(3): 154$.

1893. Recherches pour servir à l'histoire de insectes fossiles des temps primaires. $493 \mathrm{pp}$. Atlas, $44 \mathrm{pp}$.

Brauer, F.

1886. Ansichten über die paläozoischen Insekten und deren Deutung. Ann. k.k. Nat. Hofmus., Wien, 1: 87-125.

Carpenter, F. M.

1930. The Lower Permian Insects of Kansas. Part 3. The Protohymenoptera. Psyche, $37(4): 343-374$.

1933. The Lower Permian Insects of Kansas. Part 6. Delopteridae, Protelytroptera, Plectoptera and a New Collection of Protodonata, Odonata, Megasecoptera, Homoptera and Psocoptera. Proc. Amer. Acad. of Arts \& Sci., 68 (11) : 411-503.

1947. Lower Permian Insects from Oklahoma. Part 1. Introduction and the Orders Megasecoptera, Protodonata, and Odonata. Proc. Amer. Acad. of Arts \& Sci., 76 (2) : 25-54.

1951. Studies on Carboniferous Insects from Commentry, France. Part II. The Megasecoptera. Jour. of Paleont., 25(3): 336-355.

1962. A Permian Megasecopteron from Texas. Psyche, 69(1): 37-41.

1971. Adaptation among Paleozoic Insects. Proc. North Amer. Paleont. Convention, Sept. 1969. Part 1: 1236-1251.

Carpenter, F. M. and E. S. Richardson, Jr.

1969. Megasecopterous Nymph in Pennsylvanian Concretions from Illinois. Psyche, 75 (4) : 295-309.

1971. Additional Insects in Pennsylvanian Concretions from Illinois Psyche, 78 (4) : 267-295.

Crampton, G. C.

1927. Eugereon and the ancestry of the Hemiptera, psocids, and Hymenoptera. Bull. Brook. Ent. Soc. 22: 1-17. 
HANDLIRSCH, A.

1906. Die fossilen Insekten und die Phylogenie der rezenten Formen. Leipzig. $430 \mathrm{pp}$.

KuKalová, J.

1961. Paläozoische Insekten in der Tschechoslowakei. Proc. XI. Int. Entomol. Congress: 290-294.

1969. Revisional Study of the Order Palaeodictyoptera in the Upper Carboniferous Shales of Commentry, France. Part 1. Psyche, $76(2)$ : 163-215; Part 2. Psyche, 76(4) : 439-486; Part 3. Psyche, $77(1):(1970): 1-44$.

LAMEere, A.

1908. La paléontologie et les métamorphoses des insectes. Ann. Soc. Ent. Belgique, 52: 127-149.

1917. Note sur les insectes houillers de Commentry. Bull. Soc. Zool. Fr., 42: 27-37.

1917. Revision sommaire des insectes fossiles du Stephanien de Commentry. Bull. Mus. Paris, 23 : 141-200.

LAURENTIAUX, D.

1952. Découverte d'un rostre chez Stenodictya lobata Brgt. (Paléodictyoptère sténodictyide) et le problème des Protohémiptères. Bull. Soc. Géol. Fr., sér. 6, $2:$ 233-247.

1953. Classes des Insectes. In Traité de Paléontologie (Piveteau), Paris. $3: 415$.

Martynov, A. V.

1938. Études sur l'histoire géologique et de phylogenie des ordres des insectes (Pterygota). le partie. Trav. Inst. Paléont. Acad. Sci. U.R.S.S., $7(4): 1-150$.

1941. Permian fossil Insects from Tshekarda. Trav. Inst. Paléont. Acad. Sci. U.R.S.S., $11(1):$ 5-62.

Needham, J. G., M. J. Westfall, Jr.

1955. A Manual of the Dragonflies of North America (Anisoptera): $615 \mathrm{pp}$.

Tillyard, R. J.

1924. Kansas Permian Insects. Part 3. The New Order Protohymenoptera. Amer. Journ. Sci. (5), 8 (44) : 111-112.

WALKER, E. M.

1953. The Odonata of Canada and Alaska. I.: 292 pp.

ZALESSKY, G.

1937. Etudes des insectes permiens du bassin de la Sylva et problèmes de l'évolution dans la classe des insectes. 1. Sur un nouveau représentant des Protohymenoptères et sur les voies du procès d'évolution dans la morphologie de la nervation des ailes de ce groupe. Problemy paleont., 2-3:601-607. 

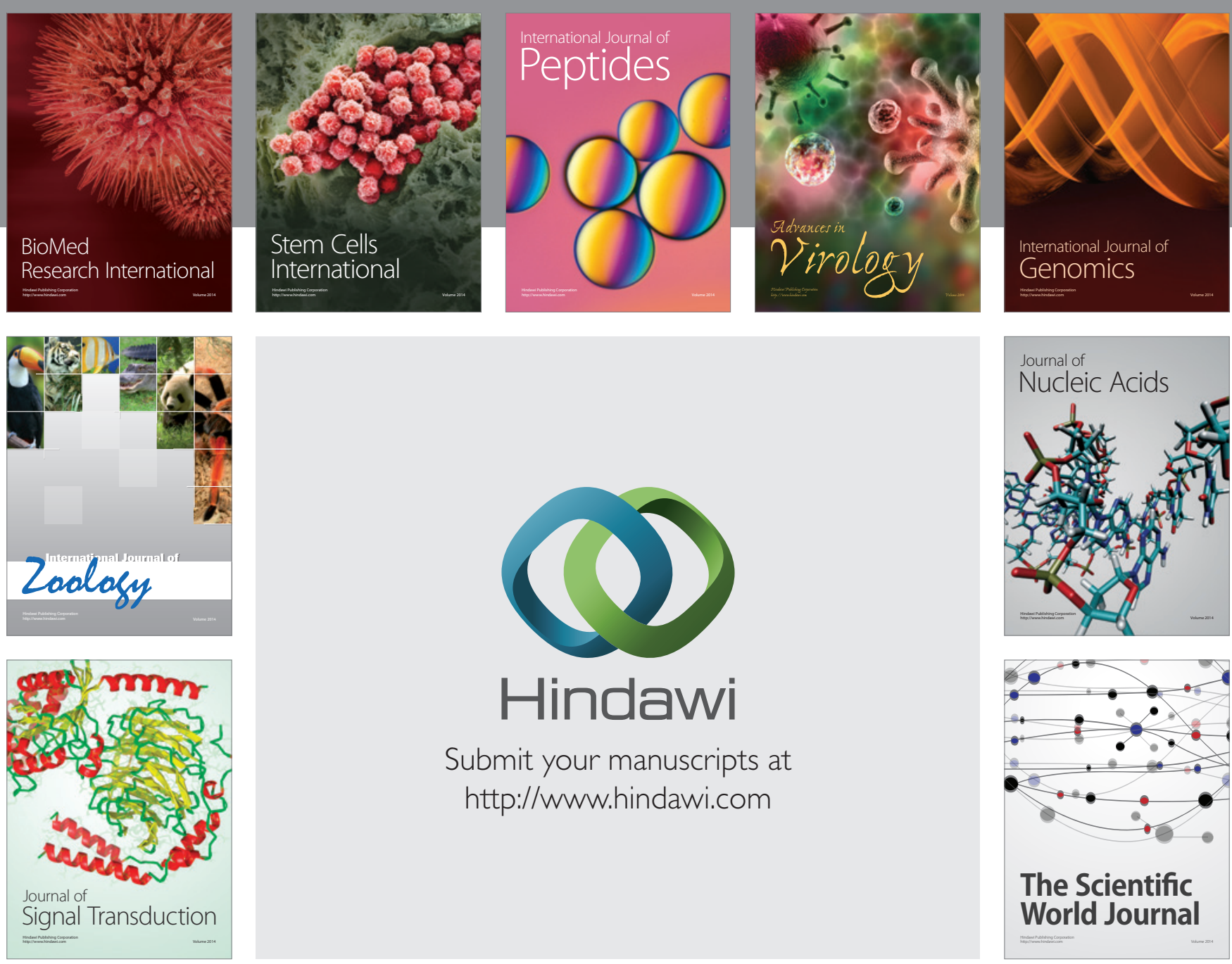

Submit your manuscripts at

http://www.hindawi.com
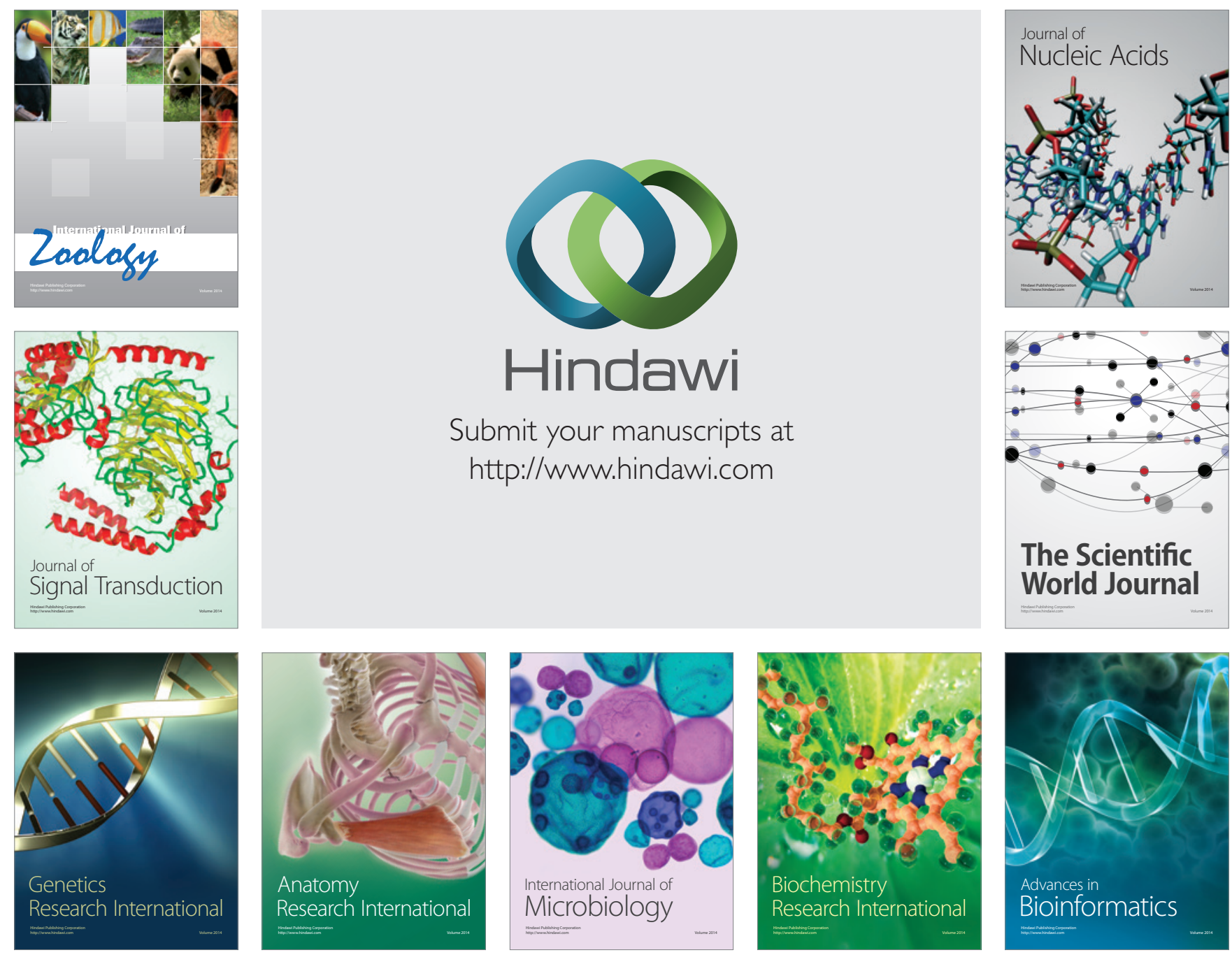

The Scientific World Journal
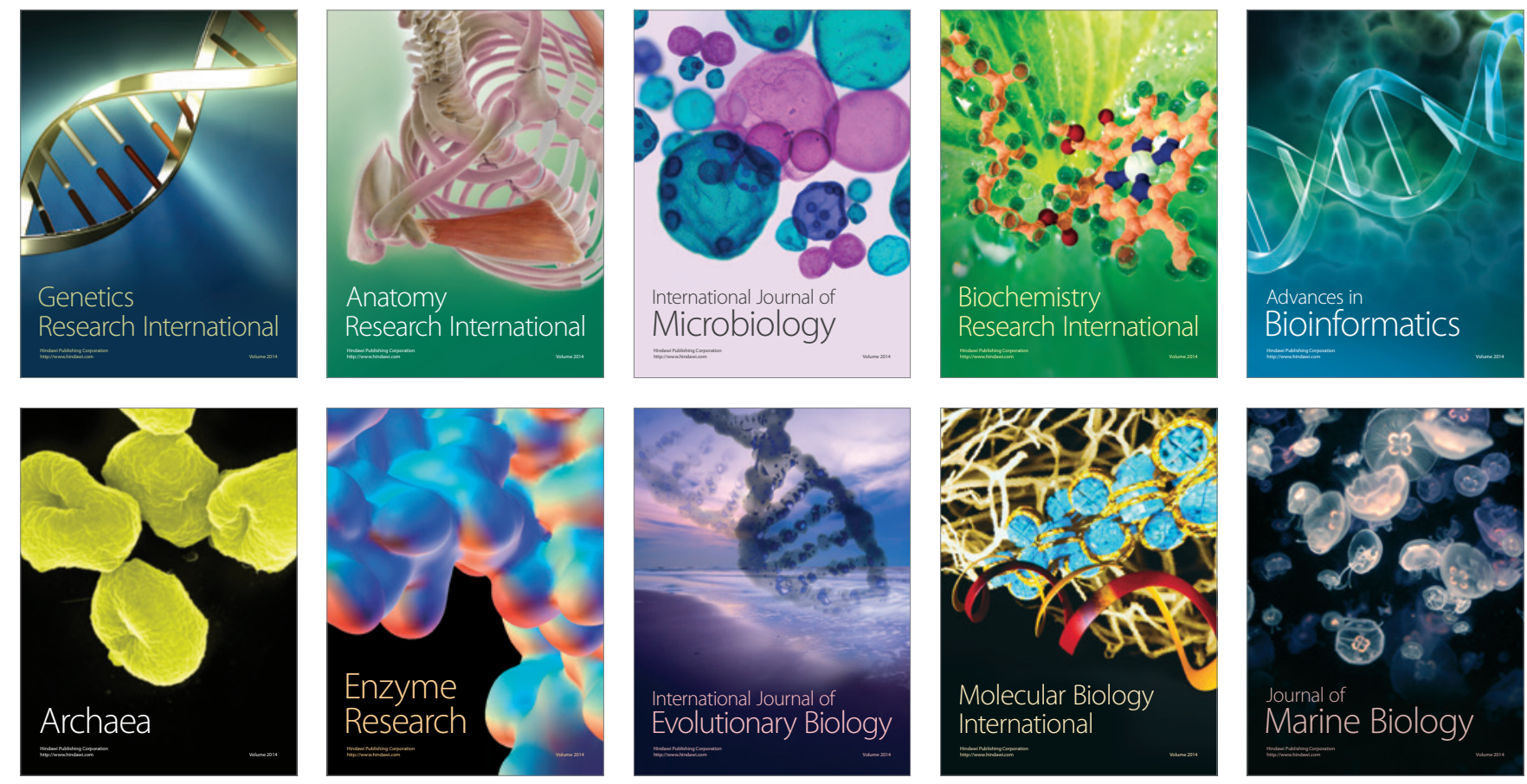